\title{
Celebrating STEM in Rural Communities: A Model for an Inclusive Science and Engineering Festival
}

\author{
Maureen Munn', Joan Griswold', Helene Starks², Stephanie M. Fullerton ${ }^{1,2}$, Conan Viernes ${ }^{3}$, Thelma Ann Sipe ${ }^{4,7}$, \\ Mike Brown ${ }^{4}$, Craig Dwight ${ }^{5}$, Randy Knuth ${ }^{6}$, and Sheldon Levias ${ }^{6,8}$
}

\begin{abstract}
${ }^{1}$ Department of Genome Sciences, University of Washington, Seattle, WA; ${ }^{2}$ Department of Bioethics and Humanities, University of Washington, Seattle, WA; ${ }^{3} U W$ GEARUP, Toppenish, WA; ${ }^{4}$ Educational Service District 105, Yakima, WA; ${ }^{5}$ Yakina Valley Technical Skills Center, Yakima, WA; ${ }^{6}$ Knuth Research, Inc., Spokane, WA, ${ }^{7}$ Prosser School District, Prosser, WA; ${ }^{8}$ College of Engineering, University of Washington, Seattle, WA.
\end{abstract}

Keywords: Science Engineering Festival, Informal Science, Rural Communities, Students, Teachers, Community Members, STEM Professionals Publication Date: January 19, 2018

DOI: https://doi.org/10.15695/jstem/v1i1.4

\begin{abstract}
For people living in rural communities, opportunities to meet STEM professionals and visit the science centers, museums, zoos, and aquariums usually found in urban areas are often limited because of geographical isolation, socioeconomic disadvantage, and in many cases, language barriers. To address this issue, two University of Washington (UW) education programs, Genome Science Education Outreach (GSEO) and UW Gaining Early Access and Readiness for Undergraduate Programs (GEARUP) collaborated to implement three annual Yakima Valley Science and Engineering Festivals in a rural area in central Washington. Working with educators and members of the community, we developed a highly inclusive format for the festivals that integrated hands-on activities and demonstrations presented by STEM professionals from around the Pacific Northwest, a showcase of student STEM projects from local secondary and college students, a VEX Robotics competition, and career and college prep information. The festivals reached a wide audience including students, teachers, and community members of all ages. In this report, we describe our approaches and discuss successes, challenges, and impacts on visitors with the hope that our experiences will inform others who are organizing similar events.
\end{abstract}

\section{INTRODUCTION}

Informal science learning occurs across a lifetime through different types of structured and unstructured experiences, such as everyday observations of the natural world, organized out-of-school science programs, exposure to science media, and visits to aquariums, zoos, museums, science centers, and other 'designed spaces.' (Dierking et al., 2003; National Research Council (NRC), 2009). All of these types of informal science learning experiences are different from, but potentially complementary to formal science education (Stocklmayer et al., 2010, NRC, 2009), and can play a part in the development of engaged, scientifically-literate learners. Benefits of informal science learning experiences include increased excitement for and engagement in learning and doing science; opportunities to explore topics of personal interest; and exposure to scientists, the tools of science and cutting edge research (NRC, 2009).

While people in rural communities are likely to have opportunities to interact with the natural environment or to participate in local structured out-of-school programs, they may have limited access to designed science learning spaces and other places where they can meet STEM professionals, which are more commonly located in urban areas. Factors influencing access can include geographical isolation, socio- economic disadvantage, and sometimes language barriers. To address these issues, we presented three annual Yakima Valley Science and Engineering Festivals to bring the experiences often shared in 'designed spaces' to a rural part of Washington State.

Like many parts of the United States, Washington is made up of a population-dense urban area (along the I-5 corridor from Seattle to Olympia) and large rural regions studded with towns and small cities. The Yakima Valley in central Washington is a rural agricultural area located about three hours from Seattle on the east side of the Cascade Mountain range. The population of Yakima County is very diverse, consisting of $48.8 \%$ Latinos, $6.4 \%$ Native Americans, $1.5 \%$ each Black or African American and Asian, 2.8\% two or more races, and $43.8 \%$ White, not Latino (United States Census Bureau, 2016). It includes the Yakama Indian Nation Reservation, which has a population of over 7,500 (Northwest Portland Area Indian Health Board, 2015). Most (93\%) of the Latino population in the Valley is Mexican-American (United States Census Bureau, 2011) and 21\% of the population in the Yakima Valley lives below the poverty line (University of Washington, 2014). Many schools in the Lower Yakima Valley have among the highest percentage of students of col- 
or, and the highest rates of poverty and of limited English proficiency in the entire state (OSPI, 2015).

At the outset of the project, two University of Washington (UW) science education programs, Genome Sciences Education Outreach (GSEO) and UW Gaining Early Access and Readiness for Undergraduate Programs (UW GEARUP) teamed up with educators in the Yakima Valley to plan the first of three science and engineering festivals. Physically located in the Yakima Valley and in operation since 1999, UW GEARUP is well connected to the region's academic, business, and STEM communities. At the start of this collaboration, GSEO had just begun a new project to work with teachers and the community in the Yakima Valley, and UW GEARUP provided an entrée to local community members, business leaders, and education and STEM/healthcare professionals. Although new to the Yakima Valley, GSEO had 18 years of prior experience in pre-college science education, primarily in the Seattle area, with strong connections to scientists, biomedical professionals, and science educators throughout the Pacific Northwest. GSEO and UW GEARUP were joined by a third partner in planning the festivals, Educational Service District 105 (ESD 105), which supports school districts throughout south central Washington. By combining our human and fiscal resources, we were able to implement three annual festivals that enabled people of all ages to explore the excitement of research in science, engineering, and biomedical fields, learn about careers in those areas through discussions with STEM professionals, and delve into the educational and career pathways open to them.

Design of the three Yakima Valley Science and Engineering Festivals was guided by the programmatic and educational goals of the primary partners. The goals identified for the science festivals parallel the "strands of science learning" framework articulated by the Committee on Learning Science in Informal Environments (NRC, 2009) to describe valuable elements supported by informal science environments. The festival goals include:

- Engage and excite students and the community in learning about science, engineering, and biomedical professions

- Expose visitors to concepts in science, biomedicine, and engineering through hands-on activities that enable them to make predictions, build models, use scientific tools, analyze data, and discuss results

- Interest students and the community in wanting to learn more about science, biomedicine, and engineering

- Engage students in considering a career in science, biomedical fields, or engineering

- Show students and the community that there are many biomedical, engineering, and science-based jobs that can be done in the region where they live

We employed several strategies to fulfill our goals, which may be of general utility to other groups who are planning a festival. As described in the next section, these strategies included: 1) involving community members and stakeholders in festival planning; 2) defining festival activities based on community input and program goals of primary partners; 3 ) combining our resources and connections to manage the festival and recruit exhibitors; 4) solving logistical issues; and 5) developing evaluation strategies and instruments to measure festival outcomes.

\section{METHODS}

Involving community members and stakeholders in festival planning. Planning for the first festival began in June 2011, when GSEO and UW GEARUP convened a group of key education, science, health care, and community stakeholders in the Yakima Valley for a half-day meeting. The purpose of the meeting was to introduce GSEO's new project, Genes, the Environment, and Me, which was focused on teaching about gene-environment interactions and biomedical careers in high schools through curriculum development, teacher professional development, and community science celebrations. Goals of this meeting included becoming acquainted with the community, learning about their awareness and interest in genetics and biomedical careers, and beginning a conversation about the community science festival, which was a mutual goal of both GSEO and UW GEARUP. Using an Appreciative Inquiry approach (Cooperrider et al., 2008) guided by a facilitator, we worked with the attendees to create their image for a 'Dream Festival' for the Yakima Valley. Participant recommendations that were woven into the design of the three festivals included having guest speakers, interactive hands-on activities, students as presenters, scientists as mentors for students, and showcasing biomedical careers.

In subsequent years, festival planning began with a meeting of teachers and other stakeholders to assess how to build on our prior experience and improve the next festival. We also integrated comments from evaluations of previous festivals in the early planning stages so we could include input from students, teachers, and community members who were not at the meeting. This feedback led us to expand from a one-day event in Year 1 to two-day events in Years 2 and 3, and to add additional 30-60 minute workshops that could accommodate up to 30 students. In Year 3, a new partner, the Yakima Valley Technical Skills Center (YV-TECH), took on an expanded role in festival planning and provided their facility to host the event. As described below, each year GSEO and UW GEARUP took the lead in practical logistics and implementation of the festivals, with input from ESD 105 and YV-TECH.

Defining festival activities. The activities included in each festival reflected the programmatic needs of the primary 
partner groups involved in planning and implementing, as well as the requests from the communities served by the festivals. This resulted in a highly inclusive event with an eclectic mix of activities that had appeal for people of all ages and educational backgrounds. For example, GSEO was primarily interested in providing access to hands-on experiences that enabled visitors to explore biomedical research and careers through exhibits, workshops, and lectures, while UW GEARUP was focused on community outreach and representation of STEM professions in the region. The primary goal of ESD 105 was to highlight the many STEM achievements of secondary and college students in the region, which they addressed by organizing the Student STEM Showcase. YV-TECH was interested in exposing teachers, students, and the community to their educational programs, which they accomplished by hosting the third festival on their campus and integrating presentations from their students and faculty with those from external exhibitors.

Recruiting exhibitors. GSEO staff built on their many connections with the science education, biomedical, and University of Washington (UW) communities to identify groups with active outreach components and an interest in presenting to this community. The three festivals showcased presentations from several science education programs funded by the National Institutes of Health (including programs funded by a Science Education Partnership Award or Science Education on Drug Abuse Partnership Award), the National Science Foundation, and NASA, as well as UW research laboratories that had developed outreach programs as required complementary activities in support of a federally-funded research or center grant. The festivals provided a unique opportunity to disseminate these programs to central Washington. For most groups recruited by GSEO, a faculty or staff point person enlisted additional volunteers from his or her department, the majority being graduate students who were interested in science outreach opportunities. GSEO provided presenters with a "tip sheet" that included elements to consider when setting up a presentation, such as how to engage students, create hands-on activities and design an enticing booth. The content-specific speaker training was carried out by the department creating the exhibit.

GEARUP invited STEM professionals from the region to highlight many of the local STEM businesses, and they organized a VEX robotics competition during the first two festivals to demonstrate local student talent through gamebased engineering challenges. In addition, GEARUP focused on fee-for-service outreach programs from regional science centers to fill the niche for hands-on science and engineering activities aimed at a wide age range. ESD 105 used connections to local schools and colleges to recruit student presenters interested in displaying STEM projects they had developed through their school, thus providing the com- munity with examples of high quality programs available at local schools.

Several steps were taken to make the festivals more accessible to the many visitors for whom Spanish was their primary language. Nearly all of the students participating in the festivals came from Washington State's Educational Service District 105, a region which is $64.2 \%$ Hispanic, with more than a quarter of the student population in transitional bilingual programs. We purposefully recruited and integrated bilingual presenters who wore badges identifying them as Spanish-speakers. At each festival, the UW chapter of the Society for the Advancement of Chicanos and Native Americans in Science (SACNAS; https://sacnasuwashington.wordpress.com) hosted a hands-on exhibit, and many of their presenters were bilingual. In addition, staff and undergraduate students from the UW College Assistance Migrant Program participated each year (CAMP; https://depts.washington.edu/omadcs/camp).

As well as hosting an exhibit about UW CAMP, several science-focused CAMP undergraduates at the 2014 festival served as co-presenters and translators at STEM exhibits from other groups. In 2014, a number of presenters remarked on the positive impact of working alongside Spanish-speaking volunteers. As reported by one bilingual co-presenter, "[A highlight for me was] being able to connect with students from around my community and know that I proved higher education and science are not impossible. Not only students but parents.... being able to go through the brain anatomy and physiology in SPANISH"! For adult visitors, the 2013 festival included five 30-minute evening lectures presented in Spanish and English, a feature that had been identified during the first community focus group. The 2014 festival hosted an evening session specifically for migrant families focused on the importance of STEM studies for their children, which included transportation to the venue. Each partner invited minority-serving organizations, scholarship providers, and college recruiters, to provide information to parents and students.

Solving logistical issues. There were several key issues that we had to address each year, which are described below.

Selecting a suitable venue. Factors involved in choosing the venue included location, availability, layout, services provided, and cost. The first two festivals were held in the Yakima Convention Center. This location offered several advantages, including familiarity to the community, a variety of room sizes, a staff able to set up presentation tables, and in-house catering. The primary disadvantage was cost, due to both rent and the required use of in-house catering, IT, and set-up services. By holding the third festival at a rentfree venue, YV-TECH, we reduced costs and were able to highlight a local educational institution that was not known to many of the local students and teachers. The culinary pro- 
gram at YV-TECH provided meals (at cost), and the faculty and students contributed much of the labor. The main drawback was that the layout was not as amenable to a large festival as the convention center had been, and some exhibits were less well attended as a result. The evening community event also had fewer participants at YV-TECH.

Selecting dates. Our considerations included avoiding scheduled school spring breaks and mandatory state testing, as well as the period when winter weather conditions could make travel difficult. We settled on mid to late March. The last two festivals were deliberately held during the UW spring break to facilitate participation by university students and faculty presenters. This enabled high participation of undergraduates from UW CAMP, many of whom were from the Yakima Valley and were home for spring break, were fluent in English and Spanish, and often known to visitors to the festival.

Making arrangements for presenters. Most of the presenters traveled several hours to volunteer at the festival, so we covered expenses related to lodging at a local hotel, meals, and travel.

Advertising in schools. Secondary schools throughout the Yakima Valley were invited to sign up to bring student groups to the festival, with initial preference given to schools served by GSEO and GEARUP. Schools were required to indicate the date and approximate times they would attend, as well as the numbers of students they were bringing. They also had the opportunity to sign up for limited-capacity workshops.

Advertising in the community. All advertising was done in both English and Spanish. In addition to commonly used approaches such as flyers, newspaper ads, and radio bulletins, we also used on-screen ads during the commercial segment at a local movie theater. Each year, a local news channel highlighted the festival just before it occurred. Certain groups, such as the Migrant Family Program, were targeted directly through their organizations.

Facilitating navigation through the festival. In Year 1, we used signs to guide people to different exhibits but got feedback that having a map and a list of presenters would have helped. These were added in Years 2 and 3 and shared with schools as a paper map or as part of an online, pre-festival PowerPoint presentation that teachers could show their students (included in the Supplemental Materials).

Photo permission from students, parents, community members, and presenters. Schools were sent photo permission forms to be signed by the parents of students under the age of 18. Students with signed forms applied a green dot to their name badge so people taking photos could recognize that they had provided a signed photo release. During the evening, adults were asked to sign a photo permission form for themselves and their children before their photographs were taken. Presenters were also asked for their permission to be photographed.
Facilitating accessibility for school and community groups. For many schools interested in sending student groups, lack of funding for substitute teachers and buses was a major barrier for their participation. We were able to pay for these expenses for schools that could not (for example, in 2014, we funded 10 of 16 school districts for bus and substitute teacher costs). Transportation was also provided for several community groups who otherwise would not be able to attend.

Funding. Festival expenses were covered through the parent grants for GSEO and UW GEARUP, as well as a gift from a local corporation. Figure 1 shows a breakdown of direct expenses for the 2013 festival ( $\$ 77,000$ in total). The 2012 festival was only one day in length, so costs would be proportionally reduced. In addition, in-kind contributions included volunteer time, (e.g. in 2014, 150 presenters x 2 days $=2880$ presenter hours), and the donation of festival space in 2014 by YV-TECH, which reduced costs by an additional $\$ 29,000$. Many of the raffle prizes were also donated.

\section{Evaluation strategies and instruments to measure festi-}

val outcomes. We were interested in collecting evaluation feedback from students, teachers, and parents/community members to assess how well we were meeting our educational goals and their overall satisfaction with the event. Evaluation processes and instruments were approved by the UW IRB (Approval \#42347 and \#44598). Examples of all evaluation instruments are available in Supplemental Materials.

Students. Three instruments were developed for students: 1) a "passport" to record which exhibits and workshops they visited, 2) a middle school survey, and 3) a high school survey. After being read a recruitment script, students arriving on a school field trip could decide whether to participate in

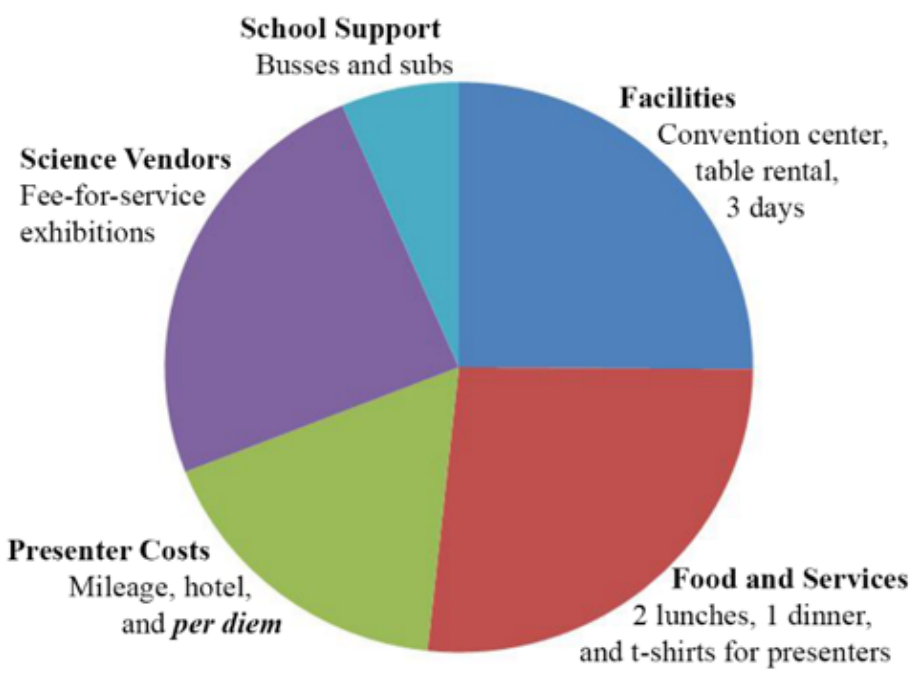

Figure 1. Breakdown of expenses by category for the 2013 festival, which spanned two days and one evening. Total costs for the event were approximately $\$ 77,000$. 
the study and if so, take a passport and survey for their grade band. Before leaving the festival, students turned in their completed surveys and passports and entered their names in a drawing for one of several prizes, which included a donated iPod, UW t-shirts, UW mugs, and science-related books.

Teachers. Teachers and other educators bringing students to the festival were asked by email to complete an online survey.

Parents/community members. During the evening session, which was open to the public, project evaluators conducted interviews in English or Spanish and/or handed out a written survey, which was printed in both languages.

\section{RESULTS}

Overview of three festivals. A comparison of the three festivals is shown in Table 1. The 2012 festival was one day long, with student groups attending during the day and community members in the evening. We extended to two days in 2013 and 2014 to accommodate more students over the two days; community members attended during the evening of the first day. Student groups came from schools throughout the Yakima Valley, some traveling 80 miles or more in each direction. The numbers of students and teachers/chaperones attending increased each year. Total attendance was around 2100 in Year 1, which increased to about 3700 in Year 2, possibly because of better advertising and/or positive feedback from the first festival. However, in Year 3, participation dropped to about 2260 due to a precipitous drop in attendance by community members (down to 350 , compared with over 2000 in Year 2). This decline may have resulted from the change in venue to YV-TECH, a less familiar location among the local community. Using 2013 as a representative year, students from at least thirty different schools participated in the festival, all but one being public schools in the lower Yakima Valley. Of the $\sim 1450$ students who attended, $71 \%$ were middle school students.

The total number of presentations increased each year. In 2013, we introduced 30-60 minute workshops, which were very popular and thus were included in 2014. In 2013, we also held five 30 minute bilingual lectures during the evening when community members were present. The lectures were not well-attended, possibly because of competition from the hands-on activities, so they were not included in 2014. The video-taped lectures are available online (https:// gsoutreach.gs.washington.edu/news/).

A list of exhibits and workshops at the 2014 festival is given in Slide 6 of the classroom introductory Power-Point presentation in the Supplementary Materials. The 2014 presenters came from locations around Washington State and nearby Portland, Oregon. Of 77 presentations, 61 were focused on STEM research, 6 were all-age STEM hands-on activities, and 10 were primarily education or career focused. The 77 presentation booths relied on over 150 volunteers over the two-day festival. Of these volunteers, about half were outreach professionals, faculty or staff, and half were undergraduate or graduate students. A summary and highlights of the 2014 festival were captured in a video (https:// animoto.com/play/7AR3j9mxHweQbMpSwRIaPQ).

Outcomes based on feedback from festival visitors. Several findings gleaned from student feedback are presented in Table 2. Across all three festivals, most middle and high school students indicated that, as result of the festival, they had a better understanding of science, engineering, and health careers, as well as the day-to-day activities of those professionals. Across the three festivals, between $60-75 \%$ of students indicated that they were interested in pursuing careers in science, engineering, or a health profession. On average, students visited about 8 exhibits during their time at

Table 1. Comparison of 2012, 2013, and 2014 festivals

\begin{tabular}{lccc}
\hline & $\mathbf{2 0 1 2}$ festival & $\mathbf{2 0 1 3}$ festival & 2 days \\
\hline Duration & 1 day & 2 days & $\sim 1423$ \\
Number of students visiting & $\sim 1063$ & $\sim 75$ & $\sim 1800$ \\
Number of teachers/chaperones & $\sim 50$ & $\sim 2200$ & $\sim 350$ \\
$\begin{array}{l}\text { Number of community members } \\
\text { visiting }\end{array}$ & $\sim 1000$ & 47 & 17 \\
Number of external presentations & 32 & Hands-on exhibits, workshops, & Hands-on exhibits, workshops \\
Number of student presentations & 15 & bilingual speakers & 33 \\
\hline
\end{tabular}


Table 2. Student understanding of and interest in pursuing science, engineering, and health careers

\begin{tabular}{lcc}
\hline \multicolumn{1}{c}{ Middle School Students } & \\
\hline Percentage of students answering YES to Yes/No questions & 2012 & 2013 \\
& $\mathrm{n}=222$ & $\mathrm{n}=311$ \\
\hline $\begin{array}{l}\text { I have learned more about the careers that scientists, engineers, or health } \\
\text { professionals have (Goal 1) }\end{array}$ & $92 \%$ & $92 \%$ \\
\end{tabular}

I have learned more about what kinds of things a scientist, engineer, or health professional does each day (Goal 1)

$99 \%$

$97 \%$

$96 \%$

I think I want to be a scientist, engineer or health professional when I grow up (Goal 4)

$70 \% \quad 62 \%$

$65 \%$

High School Students

\begin{tabular}{|c|c|c|c|}
\hline \multirow{2}{*}{ Percentage of students answering "agree" or "strongly agree" } & 2012 & 2013 & 2014 \\
\hline & $\mathrm{n}=85$ & $\mathrm{n}=74$ & $\mathrm{n}=79$ \\
\hline $\begin{array}{l}\text { I now have a better understanding of science, engineering, and/or health } \\
\text { careers (Goal 1) }\end{array}$ & $84 \%$ & $93 \%$ & $95 \%$ \\
\hline $\begin{array}{l}\text { I now have a better understanding of the education I need to pursue a } \\
\text { career in science, engineering and/or a health profession (Goal 1) }\end{array}$ & $68 \%$ & $66 \%$ & $81 \%$ \\
\hline $\begin{array}{l}\text { As a result of the festival } I \text { have a clearer understanding of the day to day } \\
\text { activities that scientists, engineers and health professionals perform (Goal } \\
\text { 1) }\end{array}$ & $80 \%$ & $85 \%$ & $79 \%$ \\
\hline $\begin{array}{l}\text { As a result of the festival, I am now more interested in pursuing a career in } \\
\text { science, engineering, and/or a health profession (Goal 4) }\end{array}$ & $69 \%$ & $76 \%$ & $60 \%$ \\
\hline
\end{tabular}

the festival (range $=4-12$ exhibits). Across the years, the robotics competition/exhibition was a popular draw, with high numbers of visitors. Other highly-rated exhibitions across age groups included the planetarium, Casper the Colon, and booths showcasing digital media, DNA/genetics, gaming, and engineering.

Community members also indicated that they better understood biomedical, engineering, and other science careers as well as the day-to-day activities that STEM professionals perform, although not to the same extent as the students. This may in part be because most community members came with their families and spent most of the festival monitoring their children's interactions with the activities (gleaned from 2012 interview responses, data not shown).

The most insightful feedback came from teachers and other educators who brought students to the festival. Tables 3 and 4 summarize comments that reflect perspectives voiced by many of the respondents to the online teacher survey. Although this evidence is anecdotal, it demonstrates teachers' perceived impressions of the impact of the festival on their students, based on classroom discussions within a few days of attending, as well as their impressions of how they personally benefited.

The most frequent comments from teachers related to the high quality of the hands-on exhibits representing a broad range of STEM fields, as well as the opportunity to interact with engaging professionals from those fields. Their perceptions of impacts on students included high levels of excitement ("science is fun, cool, not boring," Figure 2), interest in learning new things, exploring science outside the classroom, and engagement in discussions with STEM professionals (shown in Figure 3).

Several teachers remarked that their students were well behaved and not bored (data not shown). Exposure to STEM career options, including jobs in the local community, and career awareness were also discussed by several teachers, and some described students becoming more interested in science, wanting to go to college, and wanting to pursue 
Table 3. Teacher feedback on the impact of the festival on their students, from online surveys completed in $2012(n=13), 2013$ $(n=20)$, and $2014(n=13)$

\section{Common responses to questions:}

What were the most important benefits that your students received as a result of attending the festival? ${ }^{1}$ Do you have any anecdotes from your students about how the festival personally impacted them $?^{2}$

A wide variety of hands-on exhibits 22

Exposure to STEM fields and careers

Specific exhibits were mentioned (e.g. planetarium, robotics, health exhibits, etc.)

Science is fun/not boring/fascinating/cool

Sparked interest in STEM fields and careers

Prevalence of STEM in everyday life

Wide range of presenters

Reinforced concepts taught in school/the role of education

Students expressed interest in attending YV-TECH

Awareness of STEM careers available in our area

tional goals for the three Yakima Valley Science and Engineering Festivals and have a positive impact on all those participating as visitors, presenters, and organizers. As in any multifaceted event, there were many challenges and areas for improvement, but overall our approach provided a much appreciated and inclusive celebration of science and engineering.

Strengths of approach. The following elements were critical to the success of the festivals:

- Collaborating with partners with overlapping goals and strong commitment to creating highly inclusive events that would generate engagement and excitement for STEM learning, encourage students to pursue STEM education and careers, and enable people of all ages to have fun exploring STEM fields

- Seeking input from stakeholders for each festival and using evaluation comments from previous years to improve subsequent events

- Bringing the science to the community in a central location

- Including high quality hands-on presentations from a wide range of STEM fields, with activities for people of different ages

- Providing opportunities for students to talk to and learn from STEM professionals as well as other students who are knowledgeable and excited about their field of study

- Helping to cover costs of schools and community groups by providing transportation, paying for substitute teachers, and providing meals, lodging, and travel expenses for presenters

- Involving Spanish-speaking presenters, particularly "near-peer" college-aged students from the local community

- Obtaining funding to support the cost of the festivals teacher's comment reflects this aspect of complementarity between the festival and classroom experiences:

Students got to see that education comes in many forms and sometimes that what they learn now will come in handy later on in their academic careers. They saw that science and math fields can be fascinating and it helped to undo some of their misconceptions about STEM.

On a practical level, many of the teacher comments related to the accessibility of the festival, in terms of bringing STEM to them under one roof, being able to bring a large number of students, and the low cost. Several teachers attending in 2014 appreciated getting to know about YV$\mathrm{TECH}$, although others preferred the convention center.

\section{DISCUSSION}

Based on extensive evaluation, informal feedback, and our own observations, we were able to achieve our educa-

The Committee on Learning Science in Informal Environments has identified the importance of collaboration and consultation with partners and local stake-holders as part of designing successful informal science experiences/offerings (NRC, 2009). In addition, this committee and others have emphasized the importance of culturally centered approaches, including offering experiences in a multiple languages to match the audience when possible (NRC, 2009; Pang et al., 2014).

Challenges. As for any large event involving thou-sands of people, inevitably there were logistical is-sues. These included:

- Congestion and initial confusion when directing students to activities, especially when large groups arrived at the same time

- Logistics of consenting large groups of students as they 
Table 4. Teacher feedback on the impact of the festival on themselves, from online surveys completed in 2012 ( $n=13), 2013$ ( $n=20)$, and $2014(n=13)$

Common responses to questions: What were the most important benefits that you received as a result of attending the festival ${ }^{1} \&$ Was there a personal impact for you from attending the festival ${ }^{2}$

Access

Ability to take large numbers of students

6

Hosting at YV-TECH in 2014 enabled teachers and students to learn about its programs

5

Access to student resources not available at school

Many aspects of STEM all in one building/ In our own community/easy to get to

1

Inexpensive field trip

\section{Quality and variety of exhibits}

Well put together festival/seeing all the different applications to science - agriculture, astronomy, health, physics

My students experiencing ... the professional contact/students as presenters

3

High quality of all exhibits

Hands on/interactive

2

Impact on students

Interested in learning new things/exploring science outside of the classroom/students engaged and asking questions/ seeing the excitement

Exposure to science from all different fields

Exposure to STEM job options/career awareness

Having students become more interested in science and wanting to go to college

2

Personal impact for teacher

Learning new things myself/a renewed love for what I teach and where science can be in the future

Reinforcing classes/science in a different light than in the classroom

Simple ideas for labs/new ideas to teach/motivation to give my students personal science experiments

Making connections with students and mentoring them/getting to know my students better outside the classroom

A greater conviction regarding the importance of education to our society in general and our students' future in particular

${ }^{1}$ Question asked all three years; ${ }^{2}$ Question asked in 2013 and 2014

entered the facility

- Uneven attendance across exhibits due to isolation of some display rooms and inadequate signage

- Presenter fatigue due to duration of face time and number of visitors

- Publicizing the change of venue for the event adequately to parents and community members in Year 3

The ultimate challenge was sustainability of the festivals when financial support and human resources were no longer available. Although the planning team made efforts to procure other funding and involve local business and STEM professionals in building on our efforts, we were not successful in developing a long-term strategy for the support and development of future festivals.

Impacts. Over 8000 people of all ages were exposed to the excitement of science, engineering, and biomedical fields through the three Yakima Valley Science and Engineering Festivals. The diverse presentations enabled visitors to explore STEM concepts in the context of a broad range of fields, from agriculture to wind power to biomedical research. Students from all years reported learning about science, engineering, and health careers, the day-to-day activities of these professionals, and the education they would need to get there. Over $60 \%$ of students indicated their interest in pursuing a career in a science, engineering, and/or a health profession as a result of attending a festival.

For teachers, the festivals presented an opportunity for them and their students to share in STEM learning outside of the classroom. Their experiences helped to reaffirm their love of science, gave them ideas about how to teach some concepts, and exemplified many of the concepts they were teaching to their students. Although the festivals were not 


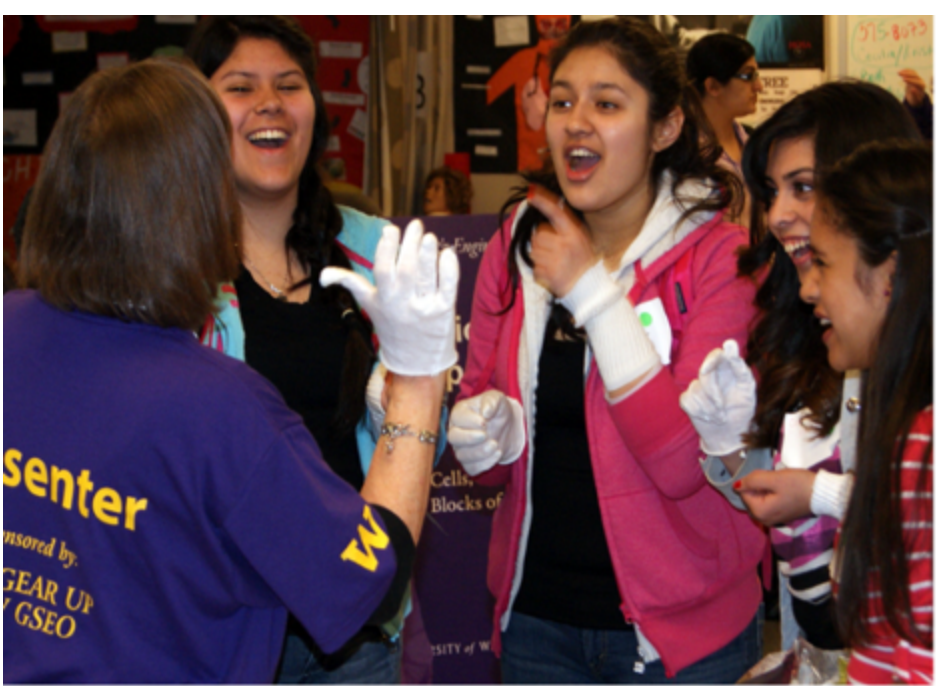

"The following day a young lady was sitting at her desk and she was grinning from ear to ear and she immediately says, 'I had so much fun let's do it again next year."' - -Teacher

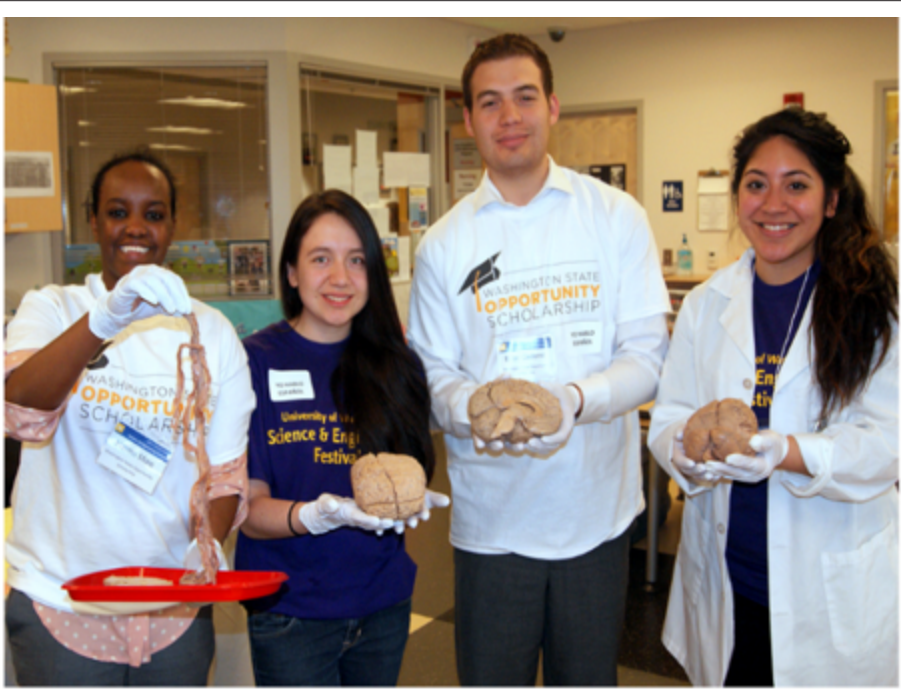

"When I woke up this morning I never thought I'd be holding a human brain in my hands today!" -Student

Figure 2. On the left, student visitors show high levels of excitement and interest in a festival exhibit and the presenter. On the right, under-graduate students representing the Washington State Opportunity Scholarship and UW CAMP serve as exhibit presenters and ham it up with brains and nervous tissue.

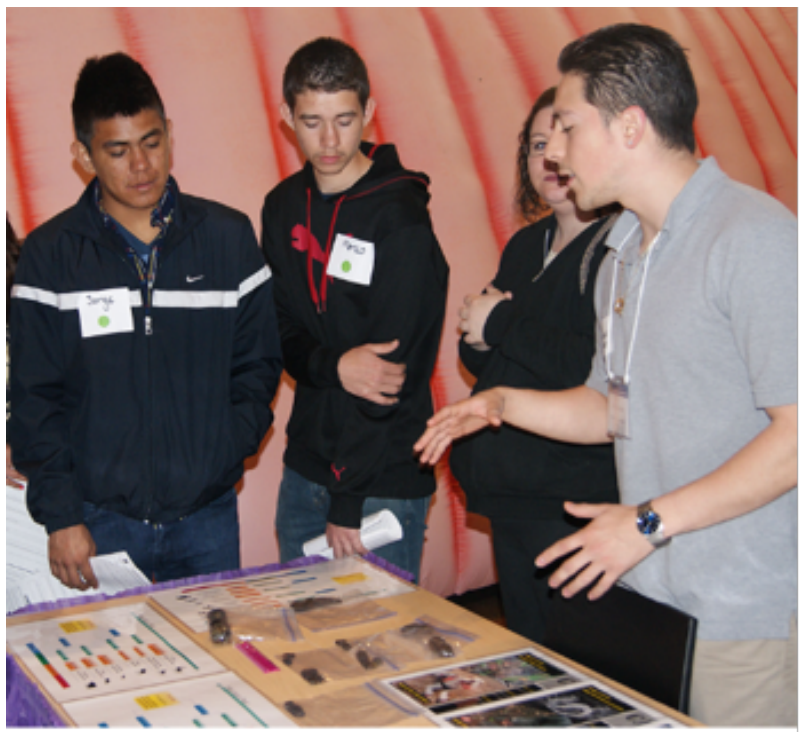

"My students got exposure to many things they do not get opportunities to experience. They benefitted from talking to professional scientists."
-Festival Teacher

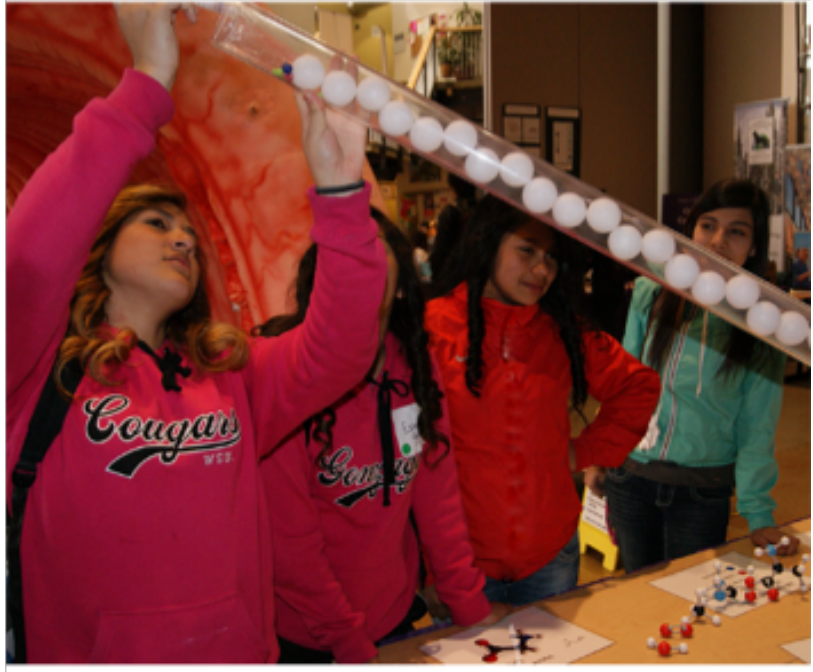

"My students benefitted from seeing science in action and applied to real-world contexts." -Festival Teacher

Figure 3. Left panel: students learn how stool samples from endangered species are used in conservation research. The presenter on the right is a UW CAMP undergraduate student. Right panel: students model how chromatography is used to separate molecules of different sizes.

designed to be linked directly to science content offered in the classroom, these informal science opportunities enriched and validated classroom curricula by enabling students and teachers to learn together and explore aspects of STEM education beyond the structures of school. In the words of one teacher, the impact of the festivals was "a greater under- standing and appreciation of the breadths of the fields represented, and a greater conviction regarding the importance of education to our society in general and our students' future, in particular." 


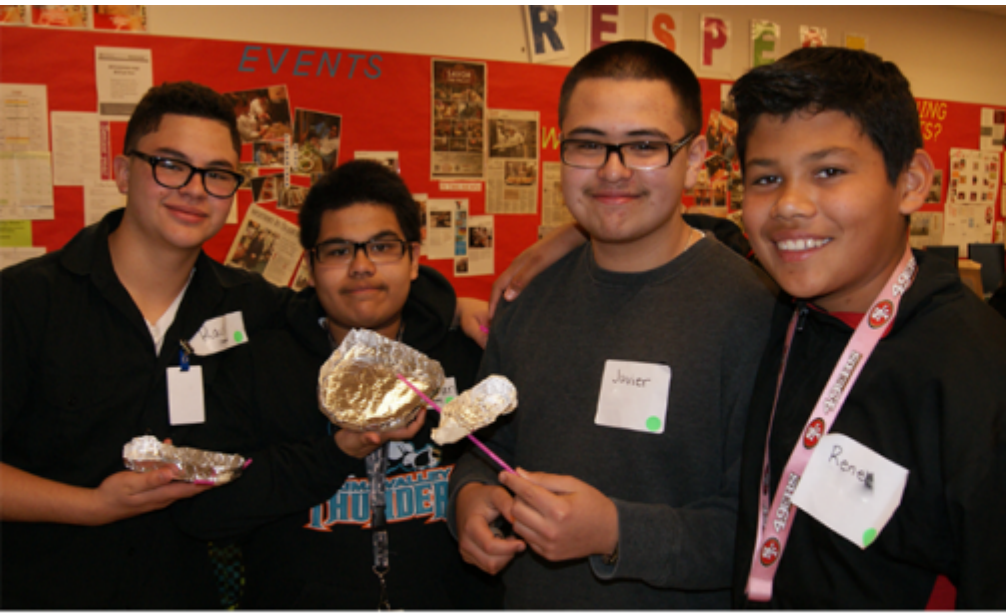

"I had several boys really enjoy the stations. Everyone appreciated the hands on science opportunities. I had several older students like talking to the college students [as] it gave them ideas about potential college majors as well as careers."

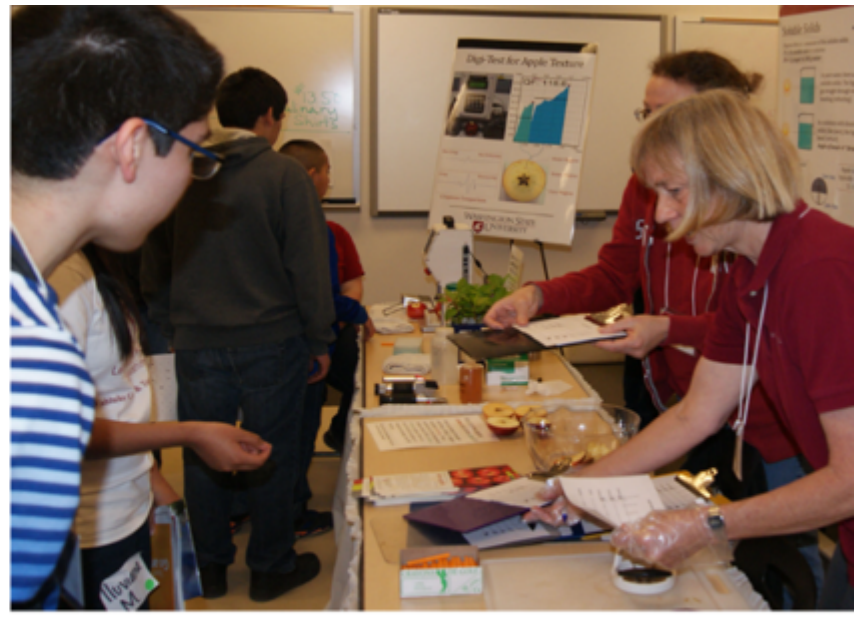

"My students benefitted from learning about STEM careers in our area."

-Festival Teacher

Figure 4. The image on the left shows students who have designed foil boats and tested their strength by measuring how many pennies they could keep afloat. As described by the teacher, the festival offered opportunities for students to discuss potential college majors and careers with near-peer presenters. The image on the right shows one of several STEM research programs in the area through a hands-on exhibit from the Washington State University Tree Fruit Research and Extension Center.

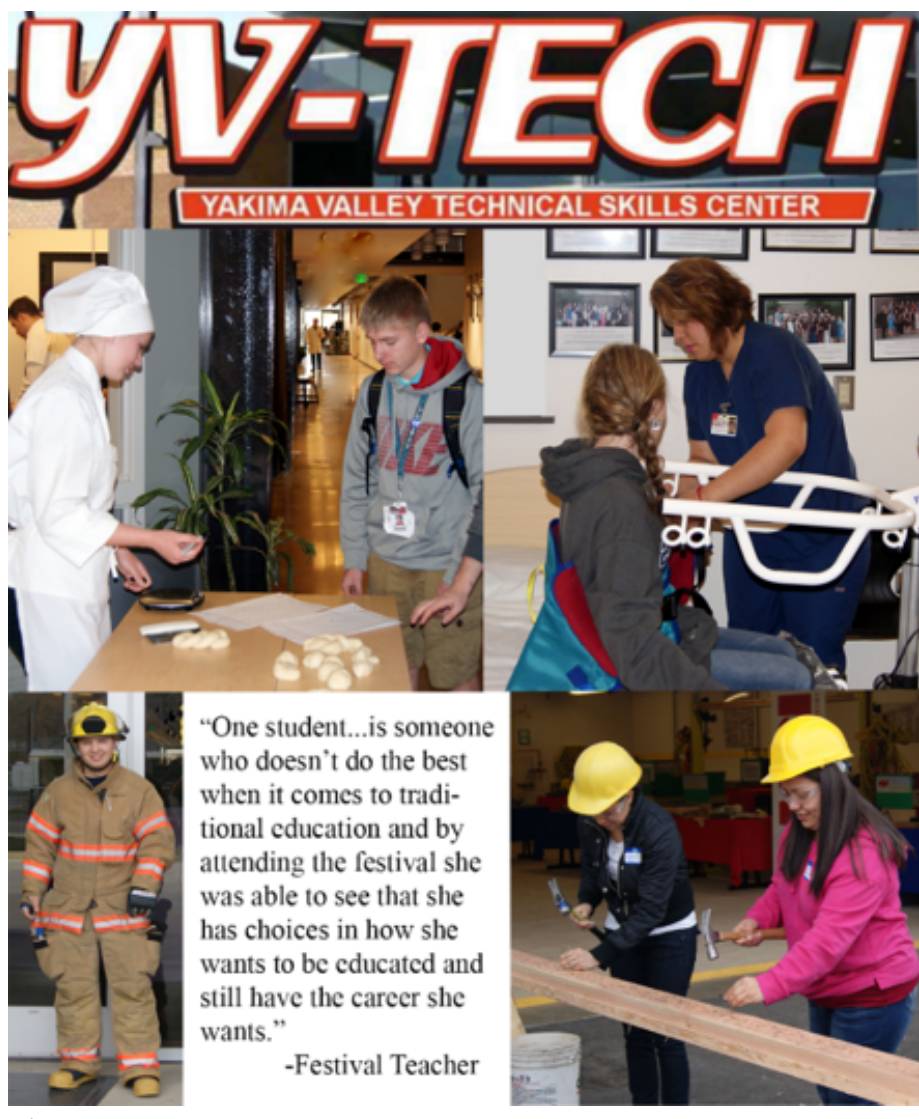

Figure 5. YV-TECH. provides technical career programs to students attending public or private high schools throughout the Yakima Valley. Typically, students attend their home high school for half the day and YV-TECH for the other half. This image depicts four of many technical training programs offered, Culinary Arts Management, Nursing Assistant, Firefighting and Carpentry/Construction.

\section{CONCLUSIONS}

Creating equitable access to high quality science education throughout the United States is a complex and multi-faceted issue because of extreme variability in geographical location, local resources, socio-economic factors, and cultural and language differences. Ideally, an individual's foundation in science is built on a variety of supporting experiences, both formal and informal. In this paper, we provide a model for bringing the STEM community to a rural area through science and engineering festivals. Alt-hough the duration of most festival visits was 2-3 hours at most, visitor feedback revealed that, at least in the short term, the festivals had a strong positive impact on their engagement, interest in, and enjoyment of science - emotional factors that have been shown to be significantly correlated with students' science literacy (Lin et al., 2012). At each of the hands-on exhibits, students and other visitors were actively engaged in scientific discussions, using scientific tools, making predictions about experimental outcomes, and examining and building models.

Although we are not able to follow up with festival visitors, our goal was to inspire future participation in other science activities. These might include visits to a science center or museum in another community, taking a walk on a nearby nature trail, talking about science around the dinner table, joining a science club or a robotics team, taking a class at YV-TECH, volunteering for a STEM organization, or taking one more STEM class than they originally planned. The festivals demonstrated that science has something to offer everyone, is about them, and could be a part of their lifelong education and career plans. 


\section{AUTHOR INFORMATION \\ Corresponding Author}

Maureen Munn, Ph.D., Department of Genome Sciences, University of Washington, Seattle, WA, mmunn@uw.edu

\section{Author Contributions}

The manuscript was written through contributions of all authors. All authors have given approval to the final version of the manuscript.

\section{FUNDING SOURCES}

This project was funded by a Science Education Partnership Award (SEPA) grant to GSEO, Grant Number R25OD010966 at the National Institutes of General Medical Sciences (NIGMS), National Institutes of Health (NIH), and by a Department of Education (DoE) GEARUP grant, Grant Number P334A110036 to UW GEARUP. The con-tents of this manuscript are solely the responsibility of the authors and do not necessarily represent the official views of the NIGMS, NIH, or DoE. We thank the Amgen Corporation in Seattle for their generous financial gift.

\section{ACKNOWLEDGEMENTS}

The authors would like to dedicate this paper to the memory of Andy Pascua, Associate Director of UW GEARUP from 2005 to 2014, who provided leadership and inspiration for the three festivals. We wish to acknowledge the following people for their many contributions to the planning and management of the festivals: Loueta Johnson, Dana Pride, Elisa Quintana, Romie Swails, Jeffrey Shaver, Dawn Counts, and Bonnie Smith. We also gratefully acknowledge the many presenters who shared their STEM field or educational program at one or more of the festivals.

\section{ABBREVIATIONS}

UW: University of Washington education programs; GSEO: Genome Sciences Education Outreach; GEARUP: UW Gain-ing Early Access and Readiness for Undergraduate Pro-grams; SACNAS: Society for the Advancement of Chicanos and Native Americans in Science; CAMP: UW College As-sistance Migrant Program; ESD: Educational Service Dis-trict; YV-TECH: Yakima Valley Technical Skills Center

\section{REFERENCES}

Cooperrider, D. L., Whitney, D., and Stavros, J. M. (2008). Appreciative Inquiry Handbook (2nd ed.). Brunswick, OH: Crown Custom Publishing, Inc.
Dierking, L. D., Falk, J. H., Rennie, L., Anderson, D. and Ellenbogen, K. (2003). Policy Statement of the "Informal Science Education" Ad Hoc Committee. Journal of Research in Science Teaching, 40, 108-111.

Lin, H.-S., Hong, Z.-R., and Huang, T.-C. (2012). The role of emotional factors in building public scientific literacy and engagement with science. International Journal of Science Education, 34, 25-42.

National Research Council. (2009). Learning Science in Informal Environments: People, Places, and Pursuits. Committee on Learning Science in Informal Environments. Bell, P., Lewenstein, B., Shouse, and Michael A.W., Feder, M.A. (Eds.) Board on Science Education, Center for Education. Division of Behavioral and Social Sciences and Education. Washington, DC: The National Academies Press.

Northwest Portland Area Indian Health Board. (2015). Member Tribes: Yakama Indian Nation. Retrieved from http://www.npaihb.org/member_tribes/tribe/yakama_indian_nation

Office of Public Instruction (OSPI). (2016). Washington State Report Card. Retrieved from http://reportcard.ospi. k12.wa.us/summary.aspx?groupLev-el=District\&schoolId=1\&reportLevel=State\&year=2013-14

Pang V.O., Lafferty K.E., Pang J.M., Griswold J., and Oser R. (2014). Culture matters in science education. Science and Children, January, 44-49.

Stocklmayer, S. M., Rennie, L. J., and Gilbert, J. K. (2010). The roles of the formal and informal sectors in the provision of effective science education. Studies in Science Education, 46, 1-44.

United States Census Bureau. (2011). Census detailed demographic profiles, Washington State Office of Financial Management. 2011. Retrieved from http:// www.ofm.wa.gov/pop/census2010/sf1/data/county/ wa_2010_sf1_county_05000US53077.pdf

United States Census Bureau, (2016). Quick Facts, Yakima County, Washington. Retrieved from https:/www. census.gov/quickfacts/fact/table/yakimacountywashington,US/AFN120212.

University of Washington. (2014). Poverty, income inequality increase in Washington state. UW Today. Retrieved from http://www.washington.edu/news/2014/09/18/ poverty-income-inequality-increase-in-washington-state/. 